\title{
Dynamics of pro-inflammatory and anti-inflammatory cytokine release during acute inflammation in chronic obstructive pulmonary disease: an ex vivo study
}

\author{
Tillie-Louise Hackett*1, Rebecca Holloway ${ }^{1}$, Stephen T Holgate ${ }^{2}$ and \\ Jane A Warner ${ }^{1}$
}

Address: ${ }^{1}$ School of Biological Sciences, University of Southampton, Southampton, UK and ${ }^{2}$ Infection, Inflammation and Repair Division, Southampton General hospital, Southampton, UK

Email: Tillie-Louise Hackett* - thackett@mrl.ubc.ca; Rebecca Holloway - rh702@soton.ac.uk; Stephen T Holgate - S.Holgate@soton.ac.uk; Jane A Warner - jawarner@soton.ac.uk

* Corresponding author

Published: 29 May 2008

Respiratory Research 2008, 9:47 doi:10.1 186/1465-992I-9-47

This article is available from: http://respiratory-research.com/content/9/1/47

(c) 2008 Hackett et al; licensee BioMed Central Ltd.

This is an Open Access article distributed under the terms of the Creative Commons Attribution License (http://creativecommons.org/licenses/by/2.0), which permits unrestricted use, distribution, and reproduction in any medium, provided the original work is properly cited.

\begin{abstract}
Background: Exacerbations of Chronic obstructive pulmonary disease (COPD) are an important cause of the morbidity and mortality associated with the disease. Strategies to reduce exacerbation frequency are thus urgently required and depend on an understanding of the inflammatory milieu associated with exacerbation episodes. Bacterial colonisation has been shown to be related to the degree of airflow obstruction and increased exacerbation frequency. The aim of this study was to asses the kinetics of cytokine release from COPD parenchymal explants using an ex vivo model of lipopolysaccharide (LPS) induced acute inflammation.
\end{abstract}

Methods: Lung tissue from 24 patients classified by the GOLD guidelines (7F/I7M, age $67.9 \pm 2.0 \mathrm{yrs}$, $\mathrm{FEV}, 76.3 \pm 3.5 \%$ of predicted) and $\mathrm{I} 3$ subjects with normal lung function $(8 \mathrm{~F}, 5 \mathrm{M}$, age $55.6 \pm 4.1 \mathrm{yrs}$, FEV $98.8 \pm 4.1 \%$ of predicted) was stimulated with $100 \mathrm{ng} / \mathrm{ml}$ LPS alone or in combination with either neutralising TNF $\alpha$ or IL- 10 antibodies and supernatant collected at I,2,4,6,24, and $48 \mathrm{hr}$ time points and analysed for IL-I $\beta$, IL-5, IL-6, CXCL8, IL-10 and TNF $\alpha$ using ELISA. Following culture, explants were embedded in glycol methacrylate and immunohistochemical staining was conducted to determine the cellular source of TNF $\alpha$, and numbers of macrophages, neutrophils and mast cells.

Results: In our study TNF $\alpha$ was the initial and predictive cytokine released followed by IL-6, CXCL8 and IL-I0 in the cytokine cascade following LPS exposure. The cytokine cascade was inhibited by the neutralisation of the TNF $\alpha$ released in response to LPS and augmented by the neutralisation of the antiinflammatory cytokine IL-10. Immunohistochemical analysis indicated that TNF $\alpha$ was predominantly expressed in macrophages and mast cells. When patients were stratified by GOLD status, GOLD I $(\mathrm{n}=$ II) and II $(n=13)$ individuals had an exaggerated TNF $\alpha$ responses but lacked a robust IL-10 response compared to patients with normal lung function $(n=13)$.

Conclusion: We report on a reliable ex vitro model for the investigation of acute lung inflammation and its resolution using lung parenchymal explants from COPD patients. We propose that differences in the production of both TNF $\alpha$ and IL-10 in COPD lung tissue following exposure to bacterial LPS may have important biological implications for both episodes of exacerbation, disease progression and amelioration. 


\section{Background}

Chronic obstructive pulmonary disease (COPD) is a major cause of mortality world wide and is predicted to be the third-leading cause of death by 2020[1]. COPD is defined by the American Thoracic society as a disease process involving progressive chronic airflow obstruction because of chronic bronchitis, emphysema or both[2]. Both the emphysematous destruction of lung tissue and the enlargement of air spaces along with excessive cough and sputum productions associated with bronchitis are believed to be related to an exaggerated inflammatory response[3]. Indeed the activation and infiltration of inflammatory cells including (CD8+) T lymphocytes, macrophages and neutrophils is a prominent feature of COPD $[4,5]$. In addition to the chronic state of inflammation observed in the airway patients with COPD are also prone to periods of exacerbation of the disease which are an important cause of the morbidity and mortality found in COPD [6-8]. COPD exacerbations are caused by a variety of factors such as viruses, bacteria and common pollutants. COPD exacerbations are now being recognised as important features of the natural history of COPD, as the frequency of exacerbations is associated with the severity of disease $[9,10]$. Statergies to reduce exacerbation frequency are thus urgently required and depend on an understanding of the inflammatory milieu associated with exacerbation episodes. The precise role of bacteria in COPD exacerbation has been difficult to asses due to approximately $30 \%$ of stable state COPD patients having bacterial colonisation within the airways[11]. The most common organism isolated from COPD patients is Haemophilus Influenzae and others include streptococcus pheumoniae and Bramhemella carrarhalis[11]. Bacterial colonisation has been shown to be related to the degree of airflow obstruction and increased exacerbation frequency[9,12-14]. More recently Stockley and colleagues have shown that COPD exacerbations associated with purulent sputum are more likely to produce positive bacterial cultures than exacerbations where the sputum was mucoid[15]. Additionally Sethi and collegues have shown that exacerbations associated with $\mathrm{H}$. influenza and $\mathrm{B}$. catarrhalis both gram negative bacteria are associated with significantly higher levels of inflammatory markers compared to pathogen-negative exacerbations[16].

Wedzicha and colleagues have shown that stable state COPD patients with high sputum levels of Interleukin-6 (IL-6) and CXCL8 have more numerous exacerbations, suggesting that the frequency of exacerbations is associated with increased airway inflammation $[17,18]$. Cytokines such as IL-6 and CXCL8 are rarely produced individually instead they are more usually released in combination with other cytokines and mediators that are characteristic of a particular disease state. These cytokine networks exhibit great pleiotropy and redundancy to the effect that any one cytokine may be influenced by another released simultaneously. TNF $\alpha$ and IL- $1 \beta$ have been identified as key cytokines that are able to initiate inflammatory cascades during exacerbations of chronic inflammatory conditions such as rheumatoid arthritis, inflammatory bowel disease, and severe asthma [19-21]. Although it is presumed that COPD exacerbations are associated with increased airway inflammation, as in patients with asthma, there is little information on the nature of the inflammatory mediator milieu during an exacerbation, especially when studied from the onset of symptoms.

In this study we aimed to assess the kinetics of key proand anti-inflammatory cytokines released from lung parenchymal explants obtained from COPD patients, using an ex vivo model of Gram negative Lipopolysaccharide (LPS) induced acute inflammation. We found that COPD disease severity was associated with an enhanced ex vivo pro-inflammatory cytokine response led by TNFa which was not ameliorated by the anti-inflammatory cytokine IL-10.

\section{Methods}

Patient characteristics for human lung tissue experiments Human parenchymal lung tissue was obtained from 37 patients $(15 \mathrm{~F} / 21 \mathrm{M})$ undergoing resection for carcinoma and 1 male undergoing surgery to remove a cyst at Guy's Hospital, London. All specimens of parenchymal tissue were obtained from sites distant from the tumour. The study was approved by the institutional ethics committee and all volunteers gave informed consent. The Global Initiative for Chronic Obstructive Pulmonary Disease (GOLD) uses a four step classification for the severity of COPD based on measurements of airflow limitation during forced expiration[22,23]. Each stage is determined by the volume of air that can be forcibly exhaled in one second $\left(\mathrm{FEV}_{1}\right)$ and by the ratio of $\mathrm{FEV}_{1}$ to the forced vital capacity (FVC); lower stages indicate less severe disease. Using the GOLD guidelines our patient cohort was stratified into the following groups, GOLD I $\left(\mathrm{FEV}_{1} / \mathrm{FVC}<70 \%\right.$, $\mathrm{FEV}_{1} \geq 80 \%$ predicted), GOLD II $\left(\mathrm{FEV}_{1} / \mathrm{FVC}<70 \%, 50 \%\right.$ $\leq \mathrm{FEV}_{1}<80 \%$ predicted) and individuals with normal lung function $\left(\mathrm{FEV}_{1} / \mathrm{FVC}>70 \%, \mathrm{FEV}_{1} \geq 90 \%\right.$ predicted)[23]. Table 1 shows the number of patients in each GOLD stage and their demographics which include age, gender, lung function and smoking history. For the purposes of this study ex-smokers were defined as individuals that had given up smoking for $\geq 3$ years to ensure for smoking cessation. All demography data was available up to the date of surgery and none of the subjects were treated prior with inhaled or oral corticosteroids or bronchodilators. 
Table I: Patient characteristics of subjects prior to the removal of lung tissue

\begin{tabular}{|c|c|c|c|}
\hline Classification & $\begin{array}{c}\text { Normal Lung Function } \\
\mathrm{FEV}_{1} / \mathrm{FVC}>70 \% \\
\mathrm{FEV}_{1} \geq 90 \% \\
\text { predicted }\end{array}$ & $\begin{array}{c}\text { GOLD I } \\
\mathrm{FEV}_{/} / \mathrm{FVC}<70 \% \\
\mathrm{FEV}_{1} \geq 80 \% \\
\text { predicted }\end{array}$ & $\begin{array}{c}\text { GOLD II } \\
\mathrm{FEV}_{1} / \mathrm{FVC}<70 \% \\
50 \% \leq \mathrm{FEV},<80 \% \\
\text { predicted }\end{array}$ \\
\hline No. subjects & 13 & 11 & 13 \\
\hline Age & $55.6 \pm 4.1$ & $69.2 \pm 2.9$ & $66.9 \pm 2.8$ \\
\hline Gender & $\begin{array}{l}8 \mathrm{~F} \\
5 \mathrm{M}\end{array}$ & $\begin{array}{l}3 F \\
8 M\end{array}$ & $\begin{array}{l}4 \mathrm{~F} \\
9 \mathrm{M}\end{array}$ \\
\hline Lung function (FEV /FVC) & $0.82 \pm 0.02$ & $0.63 \pm 0.03$ & $0.59 \pm 0.02$ \\
\hline FEV $1 \%$ predicted & $98.8 \pm 4.1$ & $90 \pm 4.0$ & $65.6 \pm 2.4$ \\
\hline \multirow[t]{3}{*}{ Smoking status } & 6 current smokers & 6 current smokers & 8 current smokers \\
\hline & 4 ex-smokers & 5 ex-smokers & 5 ex smokers \\
\hline & 3 non-smokers & & \\
\hline
\end{tabular}

Tissue samples were taken from 37 patients. Patient details including age, gender, lung function given as the ratio of air that can be forcibly exhaled in one second $\left(\mathrm{FEV}_{1}\right)$ to the forced vital capacity (FVC), $\mathrm{FEV} / \mathrm{FVC}$ and $\mathrm{FEV}, \%$ predicted and smoking status are listed as the mean $\pm \mathrm{SEM}$.

Preparation of human lung tissue for primary cell culture The procedure for preparation of human lung tissue has been described previously elsewhere[24]. Briefly, resected lung tissue was dissected free of tumour, large airways, pleura and visible blood vessels and finely chopped using dissecting scissors, into $2 \mathrm{~mm}^{3}$ fragments during several washes with Tyrode's buffer containing $0.1 \%$ sodium bicarbonate. Six explants (total weight approx. $30 \mathrm{mg}$ ) were incubated per well $\left(2.0 \mathrm{~cm}^{2}\right)$ of a 24 well plate with RPMI-1640 medium containing 1\% penicillin, 1\% streptomycin, and $1 \%$ gentamycin at $37^{\circ} \mathrm{C}$ in $5 \%$ carbon dioxide/air for 16 hours. Tissue was then either stimulated with $100 \mathrm{ng} / \mathrm{ml}$ LPS (Sigma-Aldrich, UK) or maintained in cell culture media alone for 1, 2, 4, 6, 24, or 48 hours. For neutralisation of TNF $\alpha$ and IL-10 bioactivity, tissue was incubated with $1 \mu \mathrm{g} / \mathrm{ml}$ of neutralising TNF $\alpha$ or IL-10 antibody or an isotype control (R\&D Systems, Minneapolis, USA) for $1 \mathrm{hr}$ prior to stimulation with $100 \mathrm{ng} / \mathrm{ml} \mathrm{LPS}$. Lung tissue fragments and supernatant were harvested at each time point and both were stored at $-80^{\circ} \mathrm{C}$ until anal- ysis. The tissue fragments were weighed to determine total tissue weight to normalize the levels of released cytokines.

\section{Immunohistochemistry of human lung tissue}

For the last 18 individuals recruited in the study the lung explants collected ( 6 per experimental condition) were embedded in glycol methacrylate (GMA), following stimulation with LPS or cell culture media alone for 1 or 6 hrs, as described above. The patient demographics which include age, gender, lung function, GOLD stage and smoking history as well as the mean number of macrophages, mast cells and lymphocytes counted for each group determined by lung function are given in table 2 . To determine the cell types responsible for TNF $\alpha$ release in response to LPS, immunohistochemical staining of the samples was conducted as previously described[25]. Briefly, serial sections of $2 \mu \mathrm{M}$ were stained immunohistochemically using the streptavidin biotin-peroxidase detection system and murine monoclonal antibodies directed to either human TNF $\alpha$ (1:100, clone 2B3A6A2, Biosource, SA), CD68 (1:200, clone PG-M1, DAKO), mast cell tryp-

Table 2: Numbers of Macrophages, Mast cells and Neutrophils in lung tissue from COPD patients and individuals with normal lung function

\begin{tabular}{|c|c|c|c|}
\hline & Normal lung Function (4M/6F) & GOLD I/II (6M/4F) & p Value \\
\hline Lung function (FEV $/$ FVC) & $0.79 \pm 0.02$ & $0.62 \pm 0.03$ & 0.05 \\
\hline FEV $1 \%$ predicted & $99.2 \pm 9.7$ & $77.2 \pm 8.5$ & 0.05 \\
\hline \multirow[t]{3}{*}{ Smoking status } & 4 current smokers & 4 current smokers & \\
\hline & 3 ex-smokers & 5 ex-smokers & \\
\hline & 2 non-smokers & & \\
\hline Age & 64.7. \pm 7.9 & $71.2 \pm 2.0$ & 0.07 \\
\hline Macrophage (CD68) cell//mm² & $2.8 \pm 0.6$ & $5.4 \pm 1.4$ & 0.10 \\
\hline Mast Cell (Tryptase) cell//mm² & $20.6 \pm 5.5$ & $17.1 \pm 3.9$ & 0.23 \\
\hline Neutrophil (Neutrophil elastase) cell/mm² & $8.1 \pm 0.7$ & $11.5 \pm 3.6$ & 0.15 \\
\hline
\end{tabular}

Patient data including lung function given as the ratio of air that can be forcibly exhaled in one second ( $\left.F E V_{1}\right)$ to the forced vital capacity (FVC), $\mathrm{FEV}_{1} / \mathrm{FVC}$ and $\mathrm{FEV}, \%$ predicted, smoking status, age and gender are listed as the mean $\pm \mathrm{SEM}$. Cell numbers are listed as the mean number of cells/ $\mathrm{mm}^{2}, \pm \mathrm{SEM}$ and the $\mathrm{p}$ value obtained when comparing the each factor between the two groups is given, $\mathrm{p}<0.05$ was considered statistically significant. 
tase $(1: 1000$, clone AA1, DAKO) or neutrophil elastase (1:500, clone NP57, DAKO). Control sections were incubated with isotype-matched immunoglobulins. The previously described camera-lucida technique was used to determine which cells per $\mathrm{mm}^{2}$ of alveolar tissue co-localised with TNFa positive staining on the serial sections[26].

\section{Enzyme-Linked Immunosorbent Assay}

The levels of each cytokine in the supernatant were measured by enzyme-linked immunosorbent assay (ELISA) and the concentration corrected for tissue weight. Human TNF $\alpha$ and IL-1 $\beta$ specific ELISA kits (limit of detection of $0.3 \mathrm{pg} / \mathrm{mg}$ of tissue and $0.1 \mathrm{pg} / \mathrm{mg}$ of tissue, respectively) were purchased from R\&D Systems Europe Ltd, Abingdon, UK. Human IL-5, IL-6, CXCL8 and IL-10 were all measured using commercially available ELISA Duosets from Biosource Europe, SA (limits of detection $0.3 \mathrm{pg} / \mathrm{mg}$ of tissue, $0.28 \mathrm{pg} / \mathrm{mg}$ of tissue, $0.26 \mathrm{pg} / \mathrm{mg}$ of tissue and $0.25 \mathrm{pg} / \mathrm{mg}$ of tissue, respectively). The manufacturer's protocol was followed for each ELISA.

\section{Lactate dehydrogenase assay}

To test for tissue viability Lactate dehydrogenase (LDH) levels were measured in lung supernatant using a commercially available assay and LDH standard from Roche (Indianapolis, USA). For a positive control, lung explants were homogenised on ice using a XL10 sonicator set at an amplitude of 2 microns, for 12 cycles of 10 seconds sonication followed by 20 seconds rest, in 10\% triton PBS buffer containing protease inhibitor cocktail (P2714, Sigma-Aldrich, UK). Following sonication samples were centrifuged at $15,000 \mathrm{~g}$ for $15 \mathrm{mins}$ at $4^{\circ} \mathrm{C}$, and supernatant removed for storage. The limit of detection for the assay was $1.95 \mathrm{ng} / \mathrm{mg}$ of tissue.

\section{Statistical Analysis}

All results were normalised using the tissue weight and are expressed as the mean \pm SEM. Before statistical evaluation, all results were tested for population normality and homogeneity of variance, and where applicable, a Student $t$ test was performed. A value of $\mathrm{P}<0.05$ was accepted as significant. Differences within standard curves were analysed by ANOVA with a Tukey/Kramer post hoc correction again a value of $\mathrm{P}<0.05$ was accepted as significant. Correlations between parameters were examined for statistical significance by Spearman's correlation. Experiments were performed on each of the patients in the cohort.

\section{Results \\ Kinetics of the acute inflammatory response in human lung tissue}

Release of the pro-inflammatory cytokine TNF $\alpha$ was significantly higher in the LPS stimulated tissue as early as 1 $\mathrm{hr}$, continued to rise at 2 and $4 \mathrm{hrs}$, and peaked at $6 \mathrm{hrs}$ (mean $=17.4 \pm 1.5 \mathrm{pg} / \mathrm{mg}$ of tissue) compared to undetectable levels in the non-stimulated controls (Figure 1A). Release of TNF $\alpha$ from LPS-stimulated tissue was dosedependant within the range of $0.1-1000 \mathrm{ng} / \mathrm{ml}$, with a maximal response at $1000 \mathrm{ng} / \mathrm{ml}$ therefore, in subsequent experiments, we used a sub-maximal LPS dose of $100 \mathrm{ng} /$ $\mathrm{ml}$. Over a $48 \mathrm{hr}$ time period there was no change in the levels of LDH in supernatants from LPS stimulated tissue, compared to buffer, indicating the absence of cytotoxic effects. While LPS can potentially activate a range of different cell types, not all pro-inflammatory cytokines were released. Figure $1 \mathrm{~B}$ shows that when the tissue was stimulated with LPS or buffer for 48 hrs there was no statistical significant difference in the levels of IL-1 $\beta$ released.

\section{Cytokine cascades in the acute inflammatory response}

As shown in figure $2 \mathrm{~A}$ the maximal increase of IL-6 occurred later than $\mathrm{TNF} \alpha$, peaking at $48 \mathrm{hrs}$ (mean = $685.7 \pm 189 \mathrm{pg} / \mathrm{mg}$ of tissue) compared to tissue challenged with buffer alone (mean $=238.3 \pm 50 \mathrm{pg} / \mathrm{mg}$ of tissue, $\mathrm{P}<0.05)$. The release of the chemokine CXCL8 followed a similar pattern to IL-6, with a maximal response occurring at $24 \mathrm{hrs}$ (mean $=1490.4 \pm 394 \mathrm{pg} / \mathrm{mg}$ of tissue) versus tissue challenged with buffer (mean = $692.3 \pm 251 \mathrm{pg} / \mathrm{mg}$ of tissue, $\mathrm{P}<0.05$ ) (figure $2 \mathrm{~B}$ ). The levels of anti-inflammatory cytokine IL-10 were still increasing between $24 \mathrm{hrs}$ and $48 \mathrm{hrs}$ (mean $=15.2 \pm 2.4 \mathrm{pg} / \mathrm{mg}$ of tissue) compared to undetectable levels in the tissue challenged with buffer $(\mathrm{P}<0.05$, figure $2 \mathrm{C})$. In contrast, IL-5 was not released in response to LPS (figure 2D).

\section{TNF $\alpha$ release at 6 hours predicts subsequent cytokine levels at 24 hours}

The kinetic data indicated that a succession of cytokines are released in response to LPS, with TNF $\alpha$ reaching maximal release first. We examined the relationship between the levels of TNF $\alpha$ released at $6 \mathrm{hrs}$ and the levels of the other cytokines measured at 24 hrs (Figures 3A, B and $3 \mathrm{C})$. The resultant data indicated that the amount of TNF $\alpha$ released at 6 hrs could be used to predict IL-6, CXCL8 and IL-10 release at 24 hrs.

If $\mathrm{TNF} \alpha$ is a key initiating step in the inflammatory cascade, then removal of TNF $\alpha$ should arrest or attenuate subsequent cytokine release. Pre-treatment of explants with a TNF $\alpha$ neutralising antibody (nTNF $\alpha \mathrm{Ab}$ ) for $1 \mathrm{hr}$ before LPS stimulation reduced the release of IL- 6 and CXCL8 back to baseline levels and the effect was still evident at 48 hrs post stimulation compared to treatment with an isotype control and LPS (figures 3D \&3E). Pretreatment with nTNF $\alpha$ Ab also completely abrogated the release of IL-10 up to 48 hrs after LPS stimulation (figure $3 \mathrm{~F})$. 

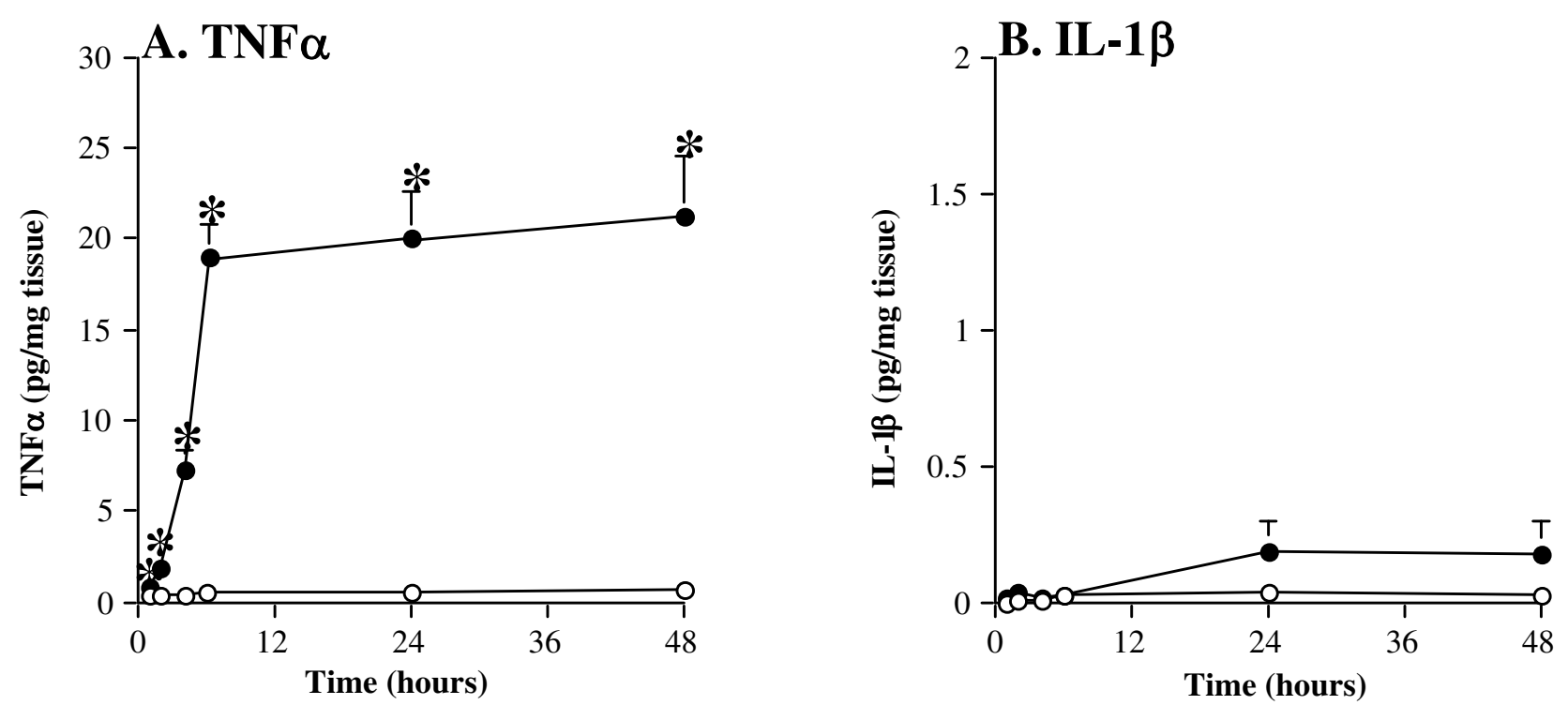

\section{Figure I}

Kinetics of the acute inflammatory response in human lung tissue. Human lung tissue $(n=37)$ was stimulated with $100 \mathrm{ng} / \mathrm{ml}$ LPS (filled circles) or buffer control (open circles). The release of (A) TNF $\alpha$ and (B) IL-I $\beta$ into the supernatant was measured by commercial ELISA. Values shown are the mean \pm SEM and are expressed as $\mathrm{pg} / \mathrm{mg}$ of tissue, $*$ indicates a $\mathrm{P}$ value $<0.05$.

\section{Co-localisation of TNF $\alpha$ with macrophages and mast cells in response to $L P S$}

As we demonstrated in figure $1 \mathrm{~A}$ that the release of TNF $\alpha$ was statistically elevated after 1 hour of LPS exposure it was important to determine which cell/cells were responsible for this early TNF $\alpha$ release. The cellular source of TNF $\alpha$ was analysed in 18 subjects (9F/9M) of the study consisting of 8 current, 7 ex and 3 non-smokers with a range of lung functions $\left(\mathrm{FEV}_{1} \%\right.$ predicted $\left.55-92 \%\right)$. To determine the inflammatory cell types responsible for $\mathrm{TNF} \alpha$ release, serial sections were stained for $\mathrm{TNF} \alpha$ and one of the following cell markers: neutrophil elastase (neutrophils), CD68 (macrophages), or mast cell tryptase (mast cells). All sections stained positively for varying amounts of neutrophil elastase, CD68 and mast cell tryptase. Figure 4 shows a representative section of lung parenchyma from a 65-year-old female smoker (FEV $183 \%$ predicted), immuno-stained with anti-TNF $\alpha$ monoclonal antibody after $1 \mathrm{hr}$ exposure to LPS (see figure 4A and 4C) and the serial sections stained for CD68 (see figure 4B) and mast cell tryptase (see figure 4D). Co-localisation of TNF $\alpha$ occurred in association with macrophages and mast cells after $1 \mathrm{hr}$ of exposure to LPS, and was consistent for all individuals studied. TNF $\alpha$ did not co-localise with neutrophil elastase staining. We also analysed tissue following 6 hours of LPS exposure however we found no difference in the cellular sources of TNF alpha. As shown in table 2, within the parenchymal tissue collected we found no statistically significant differences in the numbers and distribution of macrophages, mast cells or neutrophils within the tissue obtained from GOLDI/II patients compared to individuals with normal lung function.

\section{IL-I 0, a negative regulator of TNF $\alpha$ production}

IL-10 has been shown to act as a negative regulator of TNF $\alpha$ production $[27,28]$. We were therefore interested in studying the effects of IL-10 and whether it was able to regulate the release of TNF $\alpha$. Pre-treatment with an IL-10 neutralising antibody (nIL-10Ab) for 1 hour before LPS stimulation augmented the release of TNF $\alpha$ (figure 5A), particularly at the later time points where we previously observed maximal IL-10 release (figure $2 \mathrm{C}$ ). Since neutralising the activity of IL-10 resulted in augmented release of $\mathrm{TNF} \alpha$, we next examined if there was a similar increase in the release of any other cytokines involved in the inflammatory cascade. Pre-treatment with nIL-10 Ab also resulted in a significantly augmented release of both IL- 6 and CXCL8 at $24 \mathrm{hrs}$, which was maintained for at least 48 hrs (figures 5B \&5C).

\section{Severity of COPD influences cytokine release}

We observed large variation in cytokine release between individuals and therefore sought to assess if there was an 

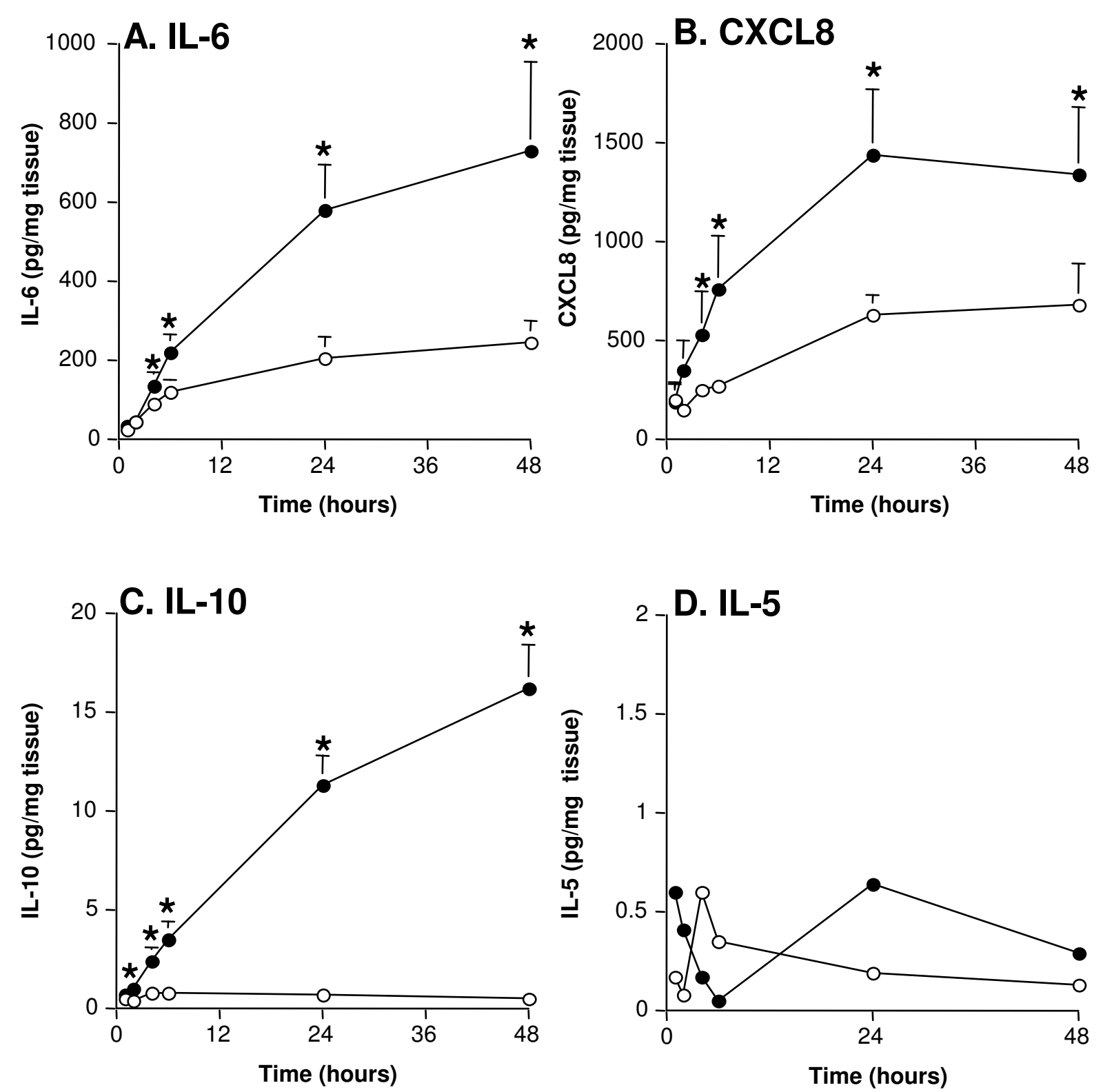

\section{Figure 2}

Cytokine cascades in the acute inflammatory response. Human lung tissue $(\mathrm{n}=37)$ was stimulated with $100 \mathrm{ng} / \mathrm{ml} \mathrm{LPS}$ (filled circles) or buffer control (open circles). The supernatants were analysed for (2A) IL-6, (2B) CXCL8, (2C) IL-I0 and (2D) IL-5 using commercially available ELISAs. For all values are the mean \pm SEM and are expressed as pg/mg tissue. $*$ indicates $P<$ 0.05 .

association between lung function and cytokine release in our explant model. Patients were classified into the following groups, normal lung function $(n=13)$, GOLD I ( $n$ $=11)$ and GOLD II $(\mathrm{n}=13)$ using the GOLD guidelines[23]. We observed that all patients showed a similar level of TNF $\alpha$ release up to the $6 \mathrm{hr}$ time point, however at $24 \mathrm{hrs}$, TNF $\alpha$ release continued to increase in individu- als classified as GOLD I and GOLD II (mean $=24.7 \pm 3.3$ and $27.6 \pm 4.2 \mathrm{pg} / \mathrm{mg}$ of tissue respectively), when compared to patients with normal lung function ( mean $=13.7$ $\pm 2.1 \mathrm{pg} / \mathrm{ml}$ of tissue, $\mathrm{P}<0.05$; figure $6 \mathrm{~A}$ ). By $48 \mathrm{hrs} \mathrm{TNF} \alpha$ release plateaued in all groups. Release of IL- 6 and CXCL8 followed a similar pattern to that observed for TNF $\alpha$ with GOLD II explants releasing elevated levels of these medi- 

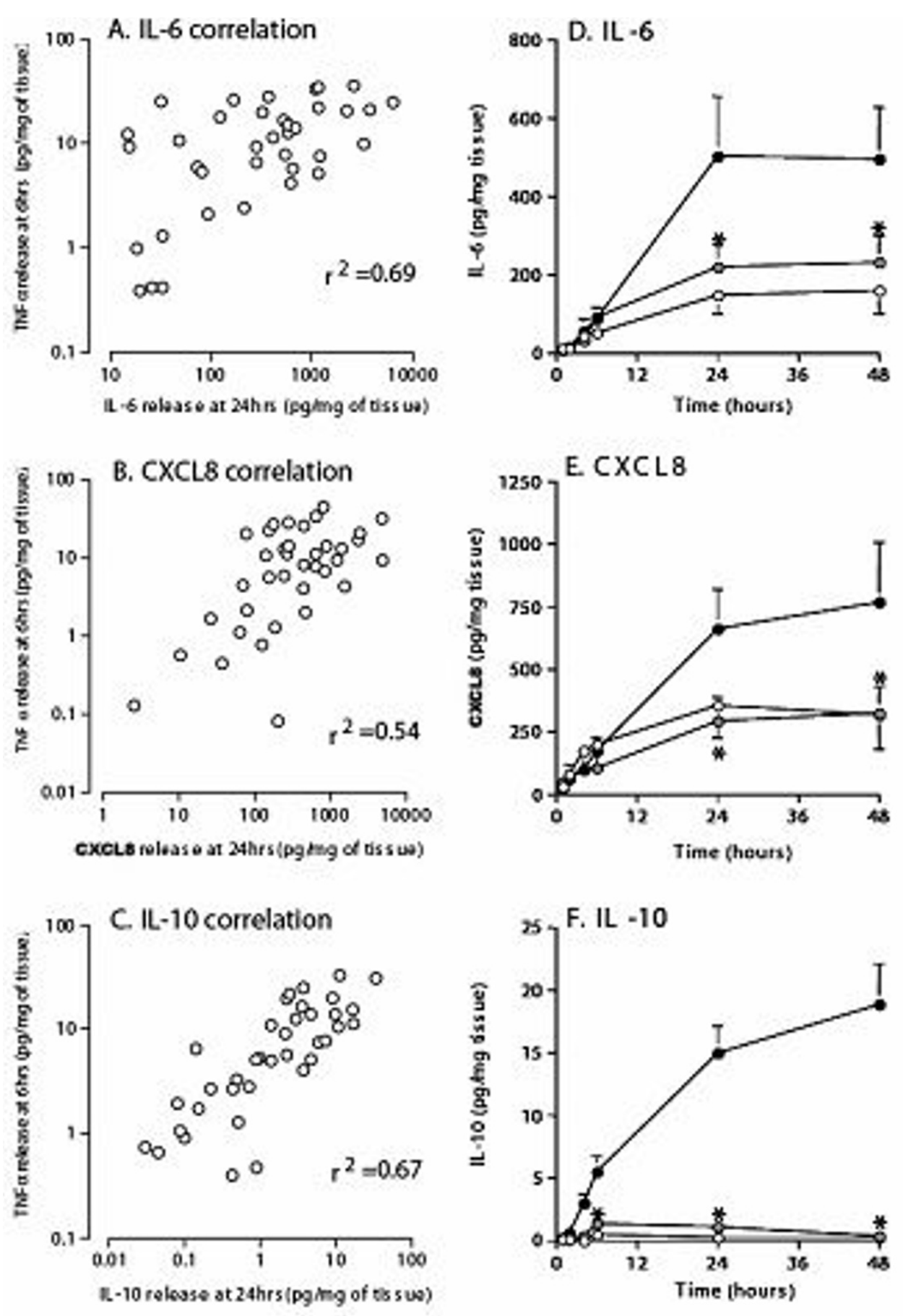

\section{Figure 3}

TNF $\alpha$, the key cytokine in the inflammatory response. Data from figures IA and $2 \mathrm{~A}, \mathrm{~B}$, and $2 \mathrm{C}$ were re-plotted to analyse the relationship between TNF $\alpha$ release at 6 hrs and IL-6 (3A), CXCL8 (3B) and IL-I0 (3C) release at 24 hrs. Data was analysed using Spearman rank correlation, the values given are the Rho and $p<0.05$. To confirm the role of TNF $\alpha$ in the cytokine cascade human lung tissue $(n=37)$ was pre-treated with neutralising TNF $\alpha$ antibody ( $\mathrm{nTNF} \alpha \mathrm{Ab})$ (grey circles) or an isotype control (open circles) for I hr and then stimulated with $100 \mathrm{ng} / \mathrm{ml}$ LPS (filled circles). The supernatants were analysed for IL-6 (3D), CXCL8 (3E), and IL-IO (3F) using commercial ELISAs. For all values given are the mean \pm SEM and are expressed as pg/ $\mathrm{mg}$ of tissue * indicates a $\mathrm{P}$ value $<0.05$. 

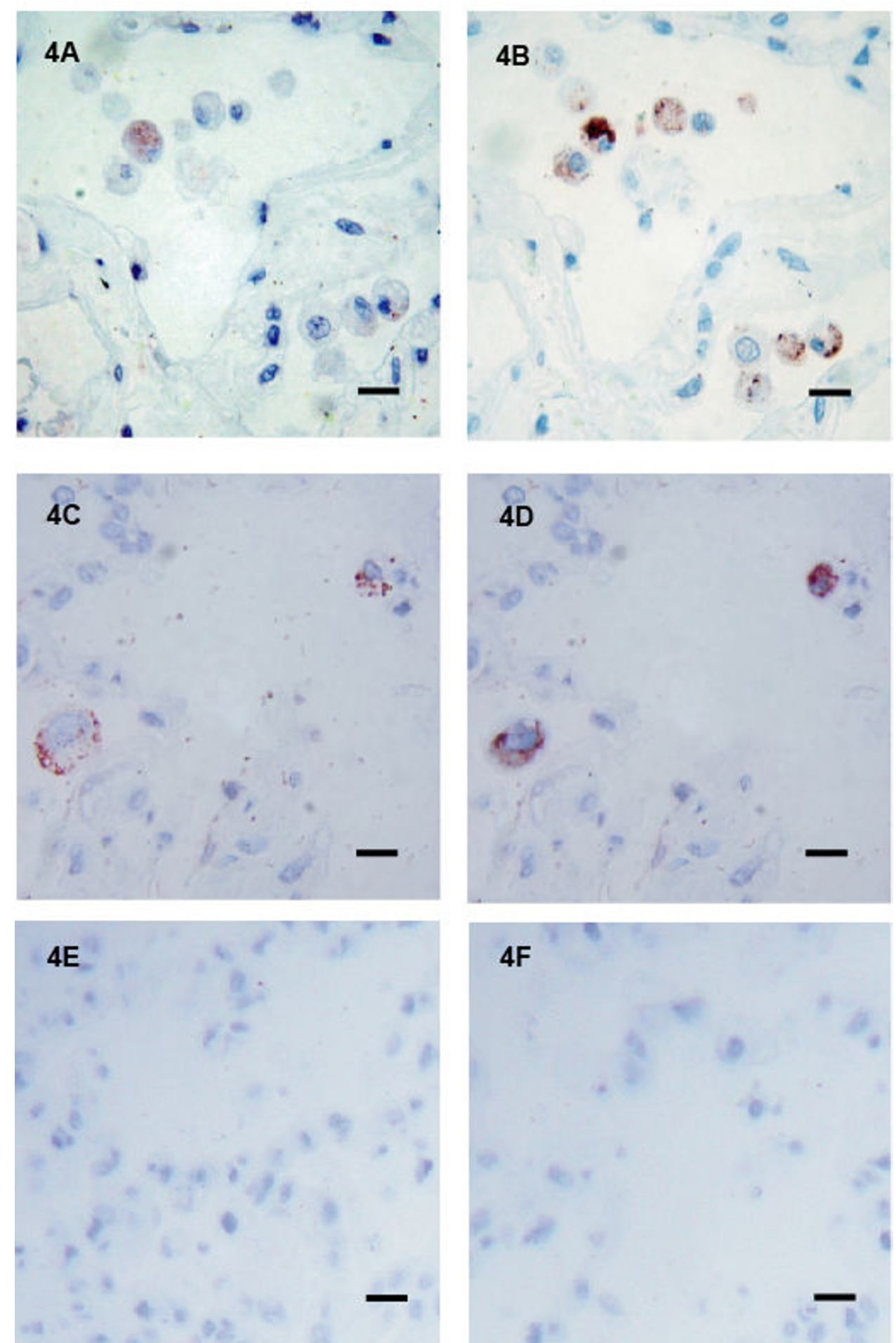

\section{Figure 4}

Co-localisation of TNF $\alpha$ with macrophages in the lung parenchyma. Lung tissue was obtained from a 65 year-old female smoker (GOLD I) stimulated with LPS for I hour. The tissue was then embedded and sequential sections of the lung parenchyma stained with monoclonal antibodies for TNF $\alpha$ (figure 4A and 4C) and CD68 (4B) and mast cell tryptase (4D). Staining specificity was determined by IgG, isotype antibody controls I:200 (4E) and I:I000 (4F) for CD68 and mast cell tryptase respectively. Bars represents $10 \mu \mathrm{m}$, positive cells are stained red. 


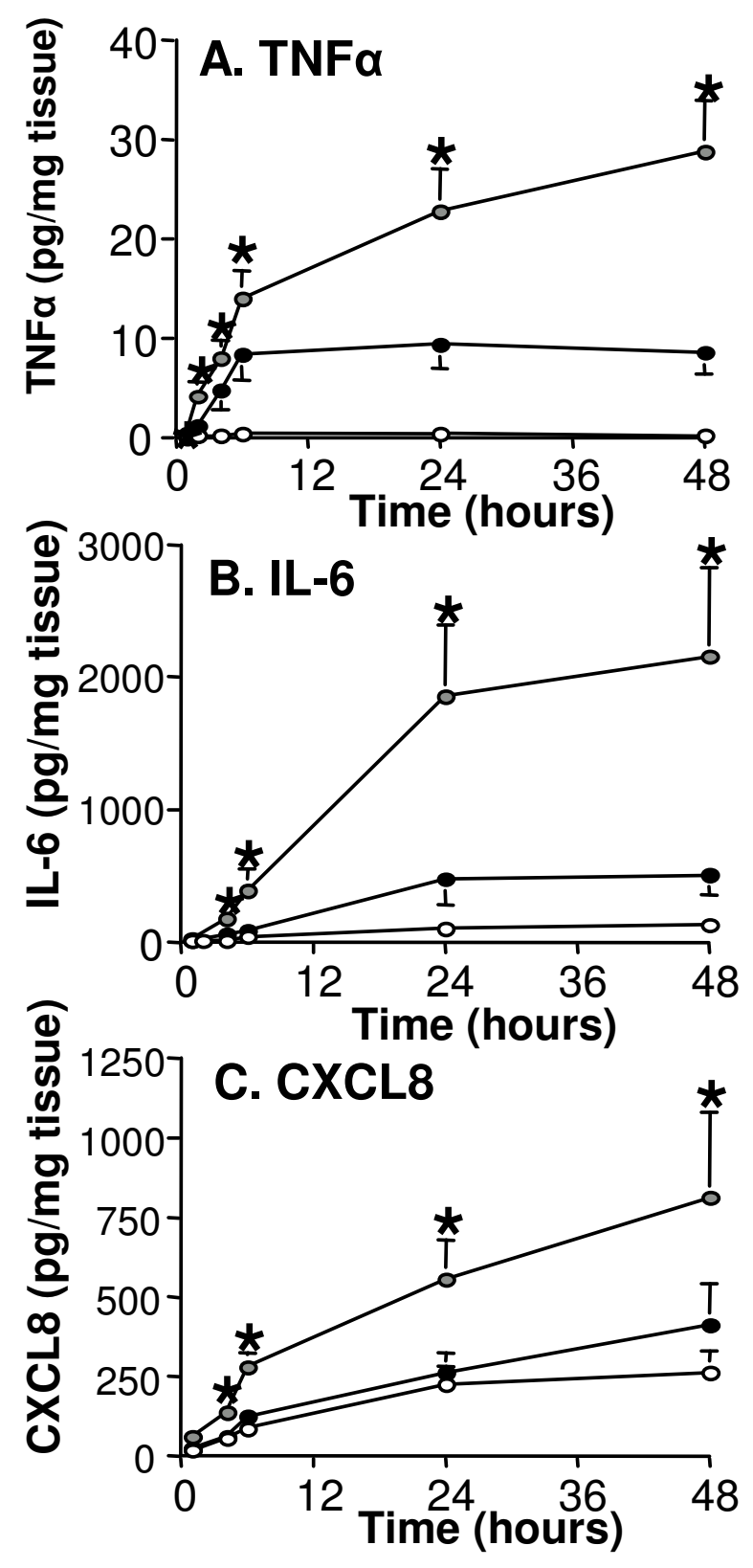

Figure 5

IL-I0, a negative regulator of TNF $\alpha$ production. Human lung tissue $(n=37)$ was pre-treated with neutralising IL- 10 antibody (nIL-IOAb) (grey circles) or an isotype control (open circles) for I hr and then stimulated with $100 \mathrm{ng} / \mathrm{ml}$ LPS (filled circles). The supernatants were analysed for (A) TNF $\alpha$, (B) IL-6, and (C) CXCL8 using commercially available ELISAs. Values given are the mean \pm SEM and are expressed as $\mathrm{pg} / \mathrm{mg}$ of tissue, $*$ indicates a $\mathrm{P}$ value $<0.05$.

ators at 24 and 48 hrs (figures 6C and 6D). In contrast, IL10 release from GOLD I (mean $=8.5 \pm 2.7 \mathrm{pg} / \mathrm{mg}$ of tis- sue) and GOLD II patients (mean $=7.8 \pm 1.8 \mathrm{pg} / \mathrm{mg}$ of tissue) was actually lower compared to patients with normal lung function $($ mean $=17.9 \pm 3.1 \mathrm{pg} / \mathrm{mg}$ of tissue, $\mathrm{P}<$ 0.05) (see figure 6B). Importantly for all of the patient demographic data collected including age, gender, and smoking status these data did not influence cytokine release in response to LPS.

\section{Discussion}

In this study, we have employed an ex vivo lung explant model to investigate the initial acute inflammatory response initiated by exposure to Gram negative bacterial cell wall component LPS in lung tissue derived from COPD patients and normal individuals. We demonstrate that lung explants obtained from COPD patients classified with mild to moderate airflow obstruction (GOLD I and II) release elevated concentrations of pro-inflammatory cytokines TNF $\alpha$, IL- 6 and CXCL8 in response to LPS but failed to mount an appropriate anti-inflammatory IL10 response when compared to normal lung tissue. We suggest that these findings may have important clinical implications for the pathogenesis of COPD as dysregulated resolution of inflammation by IL-10 could account for the exaggerated inflammation observed in COPD patients during episodes of exacerbation.

The association between bacterial colonization and the development and progression of airway inflammation in COPD has been a subject of study for several years[29,30]. Although bacteria such as $\mathrm{H}$. influenzae have been associated with COPD exacerbation, early studies have provided conflicting results as to its isolation during exacerbation [12-15]. Later evidence for the role of bacteria in COPD exacerbations has come from antibiotic therapy studies. Hill and colleagues in a large COPD study showed that the airway bacterial load was related to inflammatory markers and that the bacterial species present was related to the degree of inflammation[31]. Although the subsequent inflammatory response following a bacterial infection is considered to play a key role in the pathogenesis of COPD, the nature and sequence of the cytokine networks involved in an exacerbation have remained unexplored. The majority of clinical studies have previously concentrated on examining the acute inflammatory response during exacerbations of COPD patients using induced sputum and bronchial alveolar lavage (BAL) fluid. To our knowledge this is the first study to compare explants from patients with characterised COPD and individuals with normal lung function to investigate the kinetics of the acute inflammatory cytokine response within the distal lung towards LPS, a bacterial wall component. LPS is a widely used stimulus that acts on a number of cells within the lung through well-defined signalling cascades [32-34]. Within the literature the typical dose of LPS used in cell culture experiments and rodent models of airways disease 
is $1 \mu \mathrm{g} / \mathrm{ml}$ [35-37]. We carried out dose response curves for LPS on the tissue and deliberately chose a sub-maximal concentration of LPS $0.1 \mu \mathrm{g} / \mathrm{ml}$ in order to explore cytokine release and interactions on a number of cells within the lung explants.

In our model of acute inflammation in human lung tissue we found that TNF $\alpha$, IL-6 and CXCL8 were released following stimulation with LPS. This model using LPS mimics the cytokine profile previously reported by several groups in COPD patients with bacterial infections. In particular Solar and colleagues showed that the presence of potentially pathogenic organisms in the bronchoaleolar lavage from COPD patients was associated with a greater degree of neutrophillia and higher TNFa levels[13].
Indeed several studies have confirmed that higher bacterial load is associated with greater airway inflammation measured by elevated TNF $\alpha$, IL- 6 and CXCL8 in BAL fluid from COPD patients[13,38]. Additionally several exacerbation studies have reported elevated levels of TNF $\alpha$, IL-6 and CXCL8 in induced sputum from COPD patients admitted to hospital following an exacerbation[9,39]. Although bacterial load was not assessed in these exacerbation studies the cytokines reported, TNF $\alpha$, IL- 6 and CXCL8 are the same cytokines that we observe in our acute inflammatory model using LPS. The advantage of this model over in vivo studies is that we have been able to determine the kinetic profile of release of the cytokines most reportedly elevated in COPD patients during exacerbations.
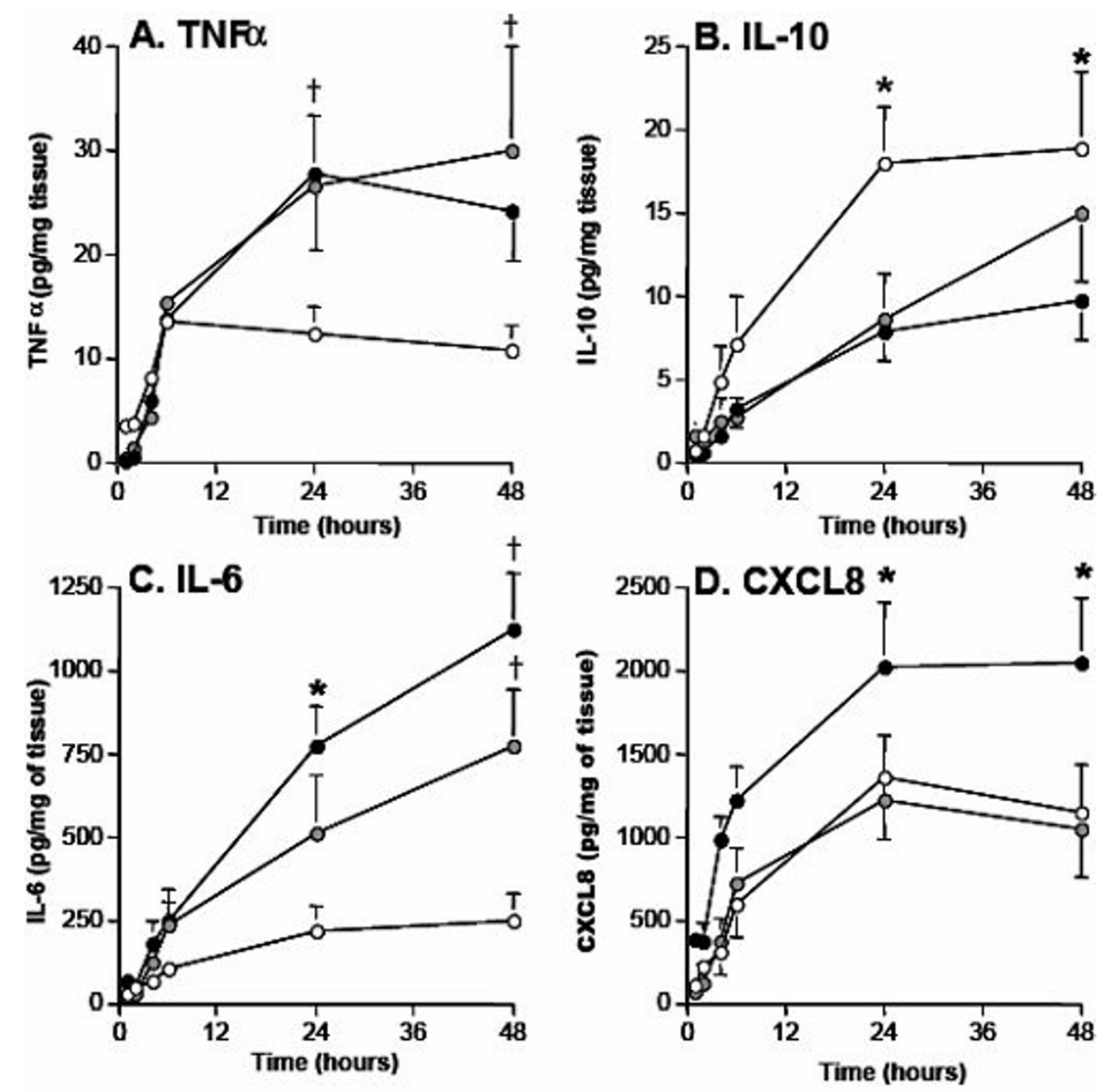

Figure 6

Severity of COPD influences cytokine release. Using the GOLD guidelines the 37 individuals in this study were classified as GOLD I (grey circles) and GOLD II (filled circles) or subjects with normal lung function (open circles). Data from figures IA, $2 A, 2 B$ and $2 C$ were then re-analysed to determine the kinetics of (A) TNF $\alpha,(B)$ IL-I0, (C) IL-6 and (D) CXCL8 release from the lung tissue of the patients in the three classified groups. Values given are the mean \pm SEM and are expressed as $P g / m g$ of tissue, $\dagger$ indicates $\mathrm{P}<0.05$ for both GOLD I and GOLD II compared to GOLD 0, and * indicates P < 0.05 for GOLD II compared to GOLD 0. 
Classification of the patients in our study using the GOLD guidelines for COPD diagnosis allowed us to segregate patients into those with normal lung function and those with mild (GOLD I) and moderate (GOLD II) COPD [23]. Using this approach, we found that lung explants from patients with GOLD I and II status had an elevated TNF $\alpha$ and subsequent IL-6 and CXCL8 response compared to explants obtained from patients with normal lung function. Our data therefore suggests that the parenchyma tissue of an individual with COPD would respond with an enhanced inflammatory response following exposure to LPS. The relationship between the magnitude of the inflammatory response and disease severity in our study may therefore have important clinical implications. Recent findings indicate that some patients with COPD develop frequent exacerbations, and recurrent exacerbations may be associated with increased airway inflammation. Indeed Bhowmik et al.,[17] reported that COPD patients with elevated concentrations of IL- 6 and CXCL8 in sputum were more likely to have frequent exacerbations, which is thought to lead to the rapid decline of lung function in these patients. In support of these findings other studies have also demonstrated a negative correlation between $\mathrm{FEV}_{1}$ and the levels of TNFa, IL- 6 and CXCL8 in sputum[39] and BAL fluid[13,38]. These in vivo studies therefore provide biological significance to our findings that release of TNF $\alpha$, IL- 6 and CXCL8 from explants in vitro negatively correlates with patients lung function. Altogether the data suggests that the heightened inflammatory response in both our model and in vivo studies of exacerbations may lead to the accelerated decline in lung function observed in COPD patients and therefore has prognostic importance for the disease. In support of these finding Donaldson and colleagues have previous reported that exacerbations in moderate to severe COPD patients contribute a greater extent to the accelerated decline in $\mathrm{FEV}_{1}$ per year observed in these patients[40]. In addition to the role of exacerbations in COPD progression the work of Hurst and colleagues has recently raised important awareness to the impact exacerbations have on systemic inflammation as they have shown that the degree of systemic inflammation observed in COPD patients is related to the extent of lower airway inflammation during exacerbation[41]. These data bring focus to the accumulating evidence of extra pulmonary manifestations in COPD including cachexia and systemic inflammation which are observed in severe COPD patients. In our model of acute inflammation we observed with disease severity elevated release of cytokines such as IL-6 which could act systemically on the liver to promote fibrinogen production. As raised levels of plasma fibrinogen is a independent risk factor of for cardiovascular disease[42]. Future studies using whole animal models would therefore be useful to determine the role exacerba- tion derived inflammatory mediators play in systemic inflammation

In our study TNFa was the initial and predictive cytokine released in the cascade following LPS exposure. Given the heterogeneity of lung tissue obtained it was of interest to characterize which cells were responsible for the TNF $\alpha$ release in our model. Applying immunohistochemistry to GMA sections, we found that macrophages and mast cells accounted for the majority of TNF $\alpha$ positive cells following LPS exposure. This finding is supported by previous data showing that endotoxins of both Gram positive and Gram negative bacteria stimulate TNF $\alpha$ release from both these cell types[26,27]. Although we observed a 0.92 fold increase in the number and distribution of TNF $\alpha$ positive cells between GOLD I/II patients and controls this difference did not reach statistical significance. An extensive small airway study by Hogg et al[43] has previously reported that the percentage of airways positive for macrophages and neutrophils is elevated in the moderate to severe stages of COPD. It is difficult to compare our observations due to the differences in atomical location of the tissue analysed, small airways verses parenchyma and the methodologies used and additonally mast cells were not analysed in the Hogg et al study. Our investigations have only been able to focus on a narrow window of the disease spectrum due to the nature of patients undergoing surgery and therefore we are unable to include GOLD III and IV patients. Therefore it is difficult to determine if the increase in the numbers of macrophages with increasing COPD severity is responsible for the elevated levels of TNF $\alpha$ observed or that macrophages and mast cells in COPD patients have an exaggerated TNF $\alpha$ response due to pre-sensitisation. Indeed it has been shown that pre-sensitisation with LPS promotes an exaggerated $\mathrm{Th}_{1}$ cytokine response in mouse models of allergic asthma[44]. Future studies are therefore required to determine if pre-sensitisation of lung tissue to bacterial agents is related to the degree of inflammation observed in COPD patients[31].

If TNFa is a key cytokine in acute airway inflammation then neutralising its biological activity could provide an important therapeutic treatment if given early enough after a COPD exacerbation. Indeed, in our model inhibition of TNF $\alpha$ activity prevented the release of IL- 6 , CXCL8 and IL-10 following LPS exposure. Blockade of TNFa activity using monoclonal antibodies or the soluble TNF $\alpha$ receptor has been used as an effective therapy in rheumatoid arthritis, inflammatory bowel disease and severe asthma [19-21]. However published reports of two clinical trials which examined the effects of the chimeric monoclonal TNF $\alpha$ antibody infliximab (Remicade) in COPD patients found no improvement in symptoms, lung function or reduction of inflammation in induced sputum $[45,46]$. The failure of anti-TNF $\alpha$ therapies may reflect 
the fact that COPD is a highly complex inflammatory disease in which many mediators are involved. However, the substantial increase in TNF $\alpha$ production following LPS exposure in our model and in vivo exacerbation studies suggests that the role of TNF $\alpha$ may be more predominant in acute inflammatory episodes rather than in the chronic disease process. Therefore future studies maybe better focused on the roles of anti-TNF therapies in preventing or modifying the severity of acute exacerbations.

Several studies have shown that IL-10 acts as a classical negative feedback inhibitor on TNFa release from macrophages $[27,47]$. In support of this mechanism of action, we report that neutralization of IL-10 activity significantly augmented LPS stimulated TNFa release from lung explants. Release of IL-6 and CXCL8 were also shown to be augmented following IL-10 inhibition, although this was likely a direct result of the increased levels of TNF $\alpha$. We also show that IL-10 release was completely abolished by neutralisation of the initial cytokine in the cascade, TNF $\alpha$. This supports a role for a delicate cytokine balance between pro-inflammatory TNF $\alpha$ and anti-inflammatory IL-10 in both resolution of inflammation and normal homeostasis of the lung. Our finding that lung tissue from GOLD I and GOLD II COPD patients releases decreased levels of IL-10 in LPS derived acute inflammation compared to patients with normal lung function has potential important pathophysiologic relevance. In support of our finding Takanashi et al[48] have also reported evidence of IL-10 disregulation in COPD as they demonstrated that the level of IL-10 in sputum from COPD patients is decreased in comparison with healthy non-smokers. As decreased expression of the anti-inflammatory mediator IL-10 could lead to the enhanced TNF $\alpha$ released observed in the COPD explants in this study. This raises important questions as to the balance of pro and anti-inflammatory mediators released within the lung during exacerbations and their cause or effect relationship to the inflammatory profile observed in COPD. One possible mechanism for altered IL-10 gene expression could be single nucleotide polymorphisms (SNP) within the gene. To date no consensus has been reached regarding any IL-10 SNP in the progression of COPD. Alternatively IL-10 gene expression could be altered epigenetically due to environmental insults such as cigarette smoke or the oxidants released in response to smoke exposure. Future studies will hopefully provide more information as to the mechanisms and outcomes involved in these modifications and their role in disease progression. As therapeutic approaches aimed at preventing the inflammatory cascade in COPD are currently focused on pro-inflammatory mediators, antiinflammatory interventions could therefore be equally if not more important. Since IL-10 is able to ameliorate the release of TNF $\alpha$ in acute inflammation, therapeutic strategies which enhance the endogenous release or activity of
IL-10 could be used to dampen TNF $\alpha$ responses without compromising the immune system, providing important targets as new therapeutic strategies for a major clinical unmet need.

Due to the nature of COPD exacerbations it is technically difficult to investigate the kinetics of acute inflammatory events within the lung following admission of patients to hospital. In this ex vivo lung explant model, we have been able to interrogate further the acute inflammatory profile in terms of the tissue's response to LPS. The use of lung explants has several advantages over isolated cell cultures, including preservation of normal tissue architecture and cellular interactions. In addition, explants can be manipulated to dissect the role of various resident cells and specific cytokines they release using neutralizing antibodies. Using this model we have been able to clarify the intrinsic response of resident cells within the lung tissue following LPS exposure and eliminate the contribution of cytokine release from circulating cells. Therefore the model also has some disadvantages as it does not entirely mimic the in vivo situation as we have not studied the role of recruited inflammatory cells following LPS exposure. Another disadvantage is the fact that lung explants are extremely heterogenous between individuals especially COPD patients, and we have tried to account for this by selecting 6 explants randomly per experimental condition. Additionally all of the explants used were dissected free of small airways and therefore the model does not represent the contribution of small airways following LPS exposure. Other causes of COPD exacerbations include viruses and common pollutants; the role of bacterial-viral or bacterialpollutant interactions may exist and have not been investigated in this study.

\section{Conclusion}

In summary, we report on a reliable ex vitro model for the investigation of acute lung inflammation and its resolution using lung parenchymal explants from COPD patients. Using this model, we propose that differences in the production of both TNF $\alpha$ and IL-10 in COPD lung tissue following exposure to bacterial endotoxin LPS may have important biological implications for both episodes of exacerbation, disease progression and amelioration. Thus further work is required to determine the role of bacterial colonization, exacerbations and airway inflammation in the pathogenesis of COPD.

\section{Competing interests}

Professor ST Holgate has received research funding from Celltech, Wyeth and Centercor in relation to the potential role of TNFa in severe asthma and has consulted with these 3 companies and UCB over the clinical trials of antiTNF therapy in asthma 


\section{Authors' contributions}

TLH carried out the tissue culture studies, immunoassays, immunohistochemistry, performed the statistical analysis and drafted the manuscript, $\mathrm{RH}$ participated with the immmunohistochemistry, STH participated in the design of the study and helped draft the manuscript, JAW conceived of the study, participated in its design, coordination and helped draft the manuscript. All authors read and approved the final manuscript.

\section{Acknowledgements}

The authors thank Prof. T Treasure and the cardiothoracic team at Guy's hospital. Members of Dr S Hurst's asthma and allergy laboratory for help with collection of lung tissue, Dr S. Wilson for her invaluable advice and expertise with the immunohistochemistry, Prof. P. Paré and Dr C. Summers for their critical evaluation of this manuscript. This work was supported by Sosei plc.

\section{References}

I. Peabody JW, Schau B, Lopez-Vidriero M, Vestbo J, Wade S, Iqbal A: COPD: a prevalence estimation model. Respirology 2005, I 0(5):594-602.

2. Standards for the diagnosis and care of patients with chronic obstructive pulmonary disease. American Thoracic Society. Am J Respir Crit Care Med 1995, I52(5 Pt 2):S77- I2I.

3. Society ATSER: Definition, Diagnosis and Staging of COPD. American Thoracic Society Website 2006 Aug 23 2006, Available from URL: [http://WWW.thoracic.org/COPD/I/definitions.asp]:.

4. Jeffery PK: Remodeling and inflammation of bronchi in asthma and chronic obstructive pulmonary disease. Proc Am Thorac Soc 2004, I(3): 176-183.

5. Cosio MG, Guerassimov A: Chronic obstructive pulmonary disease. Inflammation of small airways and lung parenchyma. Am J Respir Crit Care Med 1999, I60(5 Pt 2):S2I-5.

6. Burge S, Wedzicha JA: COPD exacerbations: definitions and classifications. Eur Respir J Suppl 2003, 4I:46s-53s.

7. Connors AF Jr., Dawson NV, Thomas C, Harrell FE Jr., Desbiens N, Fulkerson W], Kussin P, Bellamy P, Goldman L, Knaus WA: Outcomes following acute exacerbation of severe chronic obstructive lung disease. The SUPPORT investigators (Study to Understand Prognoses and Preferences for Outcomes and Risks of Treatments). Am J Respir Crit Care Med 1996, I 54(4 Pt I):959-967.

8. Donaldson GC, Seemungal TA, Patel IS, Lloyd-Owen SJ, Wilkinson TM, Wedzicha JA: Longitudinal changes in the nature, severity and frequency of COPD exacerbations. Eur Respir J 2003, 22(6):93i-936.

9. Patel IS, Seemungal TA, Wilks M, Lloyd-Owen SJ, Donaldson GC, Wedzicha JA: Relationship between bacterial colonisation and the frequency, character, and severity of COPD exacerbations. Thorax 2002, 57(9):759-764.

10. Seemungal TA, Donaldson GC, Paul EA, Bestall JC, Jeffries DJ, Wedzicha JA: Effect of exacerbation on quality of life in patients with chronic obstructive pulmonary disease. Am J Respir Crit Care Med 1998, I57(5 Pt I): 14|8-|422.

1I. Wedzicha JA: Acute Exacerbations of Chronic Obstructibe Pulmonary Disease. In Lung Biology in Health and Disease Volume 183. Edited by: Lenfan C. Informa Health Care; 2003:592: 107-I20.

12. Zalacain R, Sobradillo V, Amilibia J, Barron J, Achotegui V, Pijoan JI, Llorente JL: Predisposing factors to bacterial colonization in chronic obstructive pulmonary disease. Eur Respir J 1999, I 3(2):343-348.

13. Soler N, Ewig S, Torres A, Filella X, Gonzalez J, Zaubet A: Airway inflammation and bronchial microbial patterns in patients with stable chronic obstructive pulmonary disease. Eur Respir J 1999, I4(5): 1015-1022.

14. Monso E, Rosell A, Bonet G, Manterola J, Cardona PJ, Ruiz J, Morera $\mathrm{J}$ : Risk factors for lower airway bacterial colonization in chronic bronchitis. Eur Respir J 1999, 13(2):338-342.
15. Stockley RA, O'Brien C, Pye A, Hill SL: Relationship of sputum color to nature and outpatient management of acute exacerbations of COPD. Chest 2000, II 7(6):1638-1645.

16. Sethi S, Muscarella K, Evans N, Klingman KL, Grant BJ, Murphy TF: Airway inflammation and etiology of acute exacerbations of chronic bronchitis. Chest 2000, I I 8(6): I557-I565.

17. Bhowmik A, Seemungal TA, Sapsford RJ, Wedzicha JA: Relation of sputum inflammatory markers to symptoms and lung function changes in COPD exacerbations. Thorax 2000, 55(2): I |4-120.

18. Gompertz S, Bayley DL, Hill SL, Stockley RA: Relationship between airway inflammation and the frequency of exacerbations in patients with smoking related COPD. Thorax 200I, 56(I):36-4I.

19. Hurlimann D, Forster A, Noll G, Enseleit F, Chenevard R, Distler O, Bechir M, Spieker LE, Neidhart M, Michel BA, Gay RE, Luscher TF, Gay S, Ruschitzka F: Anti-tumor necrosis factor-alpha treatment improves endothelial function in patients with rheumatoid arthritis. Circulation 2002, 106(17):2/84-2/87.

20. Sandborn WJ: New concepts in anti-tumor necrosis factor therapy for inflammatory bowel disease. Rev Gastroenterol Disord 2005, 5(I): 10-18.

21. Howarth PH, Babu KS, Arshad HS, Lau L, Buckley M, McConnell W, Beckett P, Al Ali M, Chauhan A, Wilson SJ, Reynolds A, Davies DE, Holgate ST: Tumour necrosis factor (TNFalpha) as a novel therapeutic target in symptomatic corticosteroid dependent asthma. Thorax 2005, 60(12): 1012-1018.

22. Pauwels RA, Buist AS, Calverley PM, Jenkins CR, Hurd SS: Global strategy for the diagnosis, management, and prevention of chronic obstructive pulmonary disease. NHLBI/WHO Global Initiative for Chronic Obstructive Lung Disease (GOLD) Workshop summary. Am J Respir Crit Care Med 200I, 163(5): 1256-1276.

23. GOLD: Global strategy for the diagnosis, management, and prevention of chronic obstructive pulmonary disease. GOLD guidelines 2006 [http://WWW.goldcopd.org].

24. Schulman ES, Newball HH, Demers LM, Fitzpatrick FA, Adkinson NF $J \mathrm{r}$.: Anaphylactic release of thromboxane A2, prostaglandin D2, and prostacyclin from human lung parenchyma. Am Rev Respir Dis 198I, I 24(4):402-406.

25. Britten KM, Howarth PH, Roche WR: Immunohistochemistry on resin sections: a comparison of resin embedding techniques for small mucosal biopsies. Biotech Histochem 1993, 68(5):27I-280.

26. Bradding P, Okayama $Y$, Howarth PH, Church MK, Holgate ST: Heterogeneity of human mast cells based on cytokine content. J Immunol 1995, I 55(I):297-307.

27. Armstrong L, Jordan N, Millar A: Interleukin 10 (IL-10) regulation of tumour necrosis factor alpha (TNF-alpha) from human alveolar macrophages and peripheral blood monocytes. Thorax 1996, 5 I (2): I43-I49.

28. Gazzinelli RT, Wysocka M, Hieny S, Scharton-Kersten T, Cheever A, Kuhn R, Muller W, Trinchieri G, Sher A: In the absence of endogenous IL-10, mice acutely infected with Toxoplasma gondii succumb to a lethal immune response dependent on CD4+ $T$ cells and accompanied by overproduction of IL-I 2, IFNgamma and TNF-alpha. J Immunol 1996, I 57(2):798-805.

29. May JR: The bacteriology of chronic bronchitis. Lancet 1953, 265(6785):534-537.

30. Aaron SD, Angel JB, Lunau M, Wright K, Fex C, Le Saux N, Dales RE: Granulocyte inflammatory markers and airway infection during acute exacerbation of chronic obstructive pulmonary disease. Am J Respir Crit Care Med 200I, I 63(2):349-355.

3I. Hill AT, Campbell EJ, Hill SL, Bayley DL, Stockley RA: Association between airway bacterial load and markers of airway inflammation in patients with stable chronic bronchitis. Am J Med 2000, 109(4):288-295.

32. Armstrong L, Medford AR, Uppington KM, Robertson J, Witherden IR, Tetley TD, Millar AB: Expression of functional toll-like receptor-2 and -4 on alveolar epithelial cells. Am J Respir Cell Mol Biol 2004, 3 I (2):24I-245.

33. Supajatura V, Ushio H, Nakao A, Akira S, Okumura K, Ra C, Ogawa $\mathrm{H}$ : Differential responses of mast cell Toll-like receptors 2 and 4 in allergy and innate immunity. J Clin Invest 2002, 109(10): 1351-1359. 
34. Brewington R, Chatterji M, Zoubine M, Miranda RN, Norimatsu M, Shnyra A: IFN-gamma-independent autocrine cytokine regulatory mechanism in reprogramming of macrophage responses to bacterial lipopolysaccharide. J Immunol 200I, 167(1):392-398.

35. Chanteux H, Guisset AC, Pilette C, Sibille Y: LPS induces IL-I0 production by human alveolar macrophages via MAPKinases- and SpI-dependent mechanisms. Respir Res 2007, 8:7I.

36. Monick MM, Yarovinsky TO, Powers LS, Butler NS, Carter AB, Gudmundsson G, Hunninghake GW: Respiratory syncytial virus upregulates TLR4 and sensitizes airway epithelial cells to endotoxin. J Biol Chem 2003, 278(52):53035-53044.

37. Birrell MA, Wong S, Dekkak A, De Alba J, Haj-Yahia S, Belvisi MG: Role of matrix metalloproteinases in the inflammatory response in human airway cell-based assays and in rodent models of airway disease. J Pharmacol Exp Ther 2006, 3 I 8(2):74I-750.

38. Tumkaya M, Atis S, Ozge C, Delialioglu N, Polat G, Kanik A: Relationship between airway colonization, inflammation and exacerbation frequency in COPD. Respir Med 2007, I0I(4):729-737.

39. Hacievliyagil SS, Gunen H, Mutlu LC, Karabulut AB, Temel I: Association between cytokines in induced sputum and severity of chronic obstructive pulmonary disease. Respir Med 2006, I 00(5):846-854.

40. Donaldson GC, Seemungal TA, Bhowmik A, Wedzicha JA: Relationship between exacerbation frequency and lung function decline in chronic obstructive pulmonary disease. Thorax 2002, 57(1 0):847-852.

4I. Hurst JR, Perera WR, Wilkinson TM, Donaldson GC, Wedzicha JA: Exacerbation of chronic obstructive pulmonary disease: panairway and systemic inflammatory indices. Proc Am Thorac Soc 2006, 3(6):48I-482.

42. Danesh ], Collins R, Appleby P, Peto R: Association of fibrinogen, $C$-reactive protein, albumin, or leukocyte count with coronary heart disease: meta-analyses of prospective studies. Jama 1998, 279( I 8): | 477-I 482.

43. Hogg JC, Chu F, Utokaparch S, Woods R, Elliott WM, Buzatu L, Cherniack RM, Rogers RM, Sciurba FC, Coxson HO, Pare PD: The nature of small-airway obstruction in chronic obstructive pulmonary disease. N Engl J Med 2004, 350(26):2645-2653.

44. Delayre-Orthez C, Becker J, de Blay F, Frossard N, Pons F: Exposure to endotoxins during sensitization prevents further endotoxin-induced exacerbation of airway inflammation in a mouse model of allergic asthma. Int Arch Allergy Immunol 2005, I 38(4):298-304

45. van der Vaart H, Koeter GH, Postma DS, Kauffman HF, ten Hacken $\mathrm{NH}$ : First study of infliximab treatment in patients with chronic obstructive pulmonary disease. Am J Respir Crit Care Med 2005, I 72(4):465-469.

46. Rennard SI, Fogarty C, Kelsen S, Long W, Ramsdell J, Allison J, Mahler D, Saadeh C, Siler T, Snell P, Korenblat P, Smith W, Kaye M, Mandel M. Andrews C, Prabhu R, Donohue JF, Watt R, Lo KH, SchlenkerHerceg R, Barnathan ES, Murray J: The safety and efficacy of infliximab in moderate to severe chronic obstructive pulmonary disease. Am J Respir Crit Care Med 2007, I 75(9):926-934.

47. Fiorentino DF, Zlotnik A, Mosmann TR, Howard M, O'Garra A: IL10 inhibits cytokine production by activated macrophages. J Immunol I99I, I47( I I):38I5-3822.

48. Takanashi S, Hasegawa Y, Kanehira Y, Yamamoto K, Fujimoto K, Satoh K, Okamura K: Interleukin- 10 level in sputum is reduced in bronchial asthma, COPD and in smokers. Eur Respir J 1999 , | 4(2):309-3|4. 